\title{
Linkage Disequilibrium Mapping
}

National Cancer Institute

\section{Source}

National Cancer Institute. Linkage Disequilibrium Mapping. NCI Thesaurus. Code C19647.

Linkage disequilibrium (LD) mapping is a procedure for determining the non-random association of alleles at two or more loci on a chromosome. It is based on the premise that regions adjacent to a gene of interest are transmitted through the generations along with that gene and can be identified by the specific pattern of markers (haplotypes) that they contain, so that detection of haplotypes that are shared more frequently among groups of individuals recruited for a disease or trait can be used to locate specific genes. Linkage-disequilibrium (LD) mapping is useful in identifying genes involved in complex diseases. 